\title{
MEROMICTIC ANTARCTIC LAKES AS RECORDERS OF CLIMATE CHANGE: THE STRUCTURES OF ACE AND ORGANIC LAKES, VESTFOLD HILLS, ANTARCTICA
}

\author{
by John A. E. Gibson and Harry R. Burton \\ (with seven text-figures)
}

GibSon, J.A.E. \& BURTON, H.R., 1996 (xi): Meromictic Antarctic lakes as recorders of climate change: the structures of Ace and Organic Lakes, Vestfold Hills, Antarctica. In Banks, M.R. \& M.J. Brown (Eds): CLIMATIC SUCCESSIONAND GLACIAL HISTORY OF THE SOUTHERN HEMISPHERE OVER THE LAST FIVE MILLION YEARS. Pap. Proc. R. Soc. Tasm. 130(2): 73-78. https://doi.org/10.26749/rstpp.130.2.73 ISSN 0080-4703. Australian Antarctic Division, Channel Highway, Kingston, Tasmania, Australia 7050 QAEG, HRB) and Antarctic CRC, University of Tasmania, GPO Box 252-80, Hobart, Tasmania, Australia 7001 QAEG).

The meromictic lakes that occur in closed, rocky basins of the Vestfold Hills provide records of local climate change. From a consideration of the physical structure of these stratified lakes it is apparent that maximum winter under-ice water salinity (associated with minimum water temperatures) is a function of the water level for a particular lake. The structure of the lakes will also be affected by changes in water balance. An increase in water level will result in a lens of fresher water and warmer winter temperatures at the surface of the lake, whereas a decrease will result in increased salinity, colder temperatures and deeper epilimnetic mixing. Evidence of periods of low water level is retained by the lakes as intervals of near isopycnal water within the water column, which can be used to calculate minimum palaeolevels. Changes in the structures of Organic Lake and Ace Lake between 1975 and 1995 are used in this article to illustrate these points.

Keywords: palaeolimnology, climate change, water balance, Antarctica, Vestfold Hills.

\section{INTRODUCTION}

The lakes that occur in closed basins of the Dry Valleys and Vestfold Hills regions of Antarctica (fig. 1) have been recognised as sensitive indicators of local climate change (McKayetal. 1985, Wharton et al. 1992, Chinn 1992). The water levels in these lakes are determined by the balance between melt-water inflow from nearbyglaciers (Dry Valleys) or snow banks (Vestfold Hills) and water loss by ablation (when ice covered) and evaporation. Wharton et al. (1992) showed that the level of Lake Hoare in the Dry Valleys is related to the number of days on which the temperature is above $0^{\circ} \mathrm{C}$, i.e. "cumulative positive degree days". As ablation from the ice of these lakes appears to be nearly constant from year to year (Chinn 1992), the relationship of lake level with temperature suggests that periods of increasing lake level are associated with increased glacier melt due to warmer temperatures. Conversely, during periods of decreasing water level, melt water inflow is reduced below ablative loss, and it can be concluded that temperatures are cooler.

The situation in the lakes of the Vestfold Hills is quite different. The source of input water into these lakes is from the melting of snow banks, which build up in the lee of low hills during winter. Most of these snow banks are small and melt completely during the summer. The annual input of water into the lakes is, therefore, controlled by the size of these banks at the beginning of the summer melt. In the Dry Valleys, glaciers provide an essentially infinite water supply, limited only by the number of days of temperature greater than $0^{\circ} \mathrm{C}$ on which melting of the ice will occur. For the lakes of the Vestfold Hills, water balance will be a function of local precipitation, ablation and evaporation. A further complicating factor is that the precipitation can be either directly from snowfall or from windblown snow, which originally fell some distance inland but was subsequently remobilised and redeposited during periods of high winds.

As with closed lakes elsewhere, the water levels of the lakes of the Vestfold Hills provide a record of local climate change. At least three methods are available for studying water levels in these lakes. The simplest method is direct measurement of water level with respect to a mark of known height above (or below) sea level. Such measurements of the water level of Deep Lake have been carried out on a regular basis since 1975 (H. Burton, pers. obs.). More limited data sets exist for many other lakes in the area. However, these

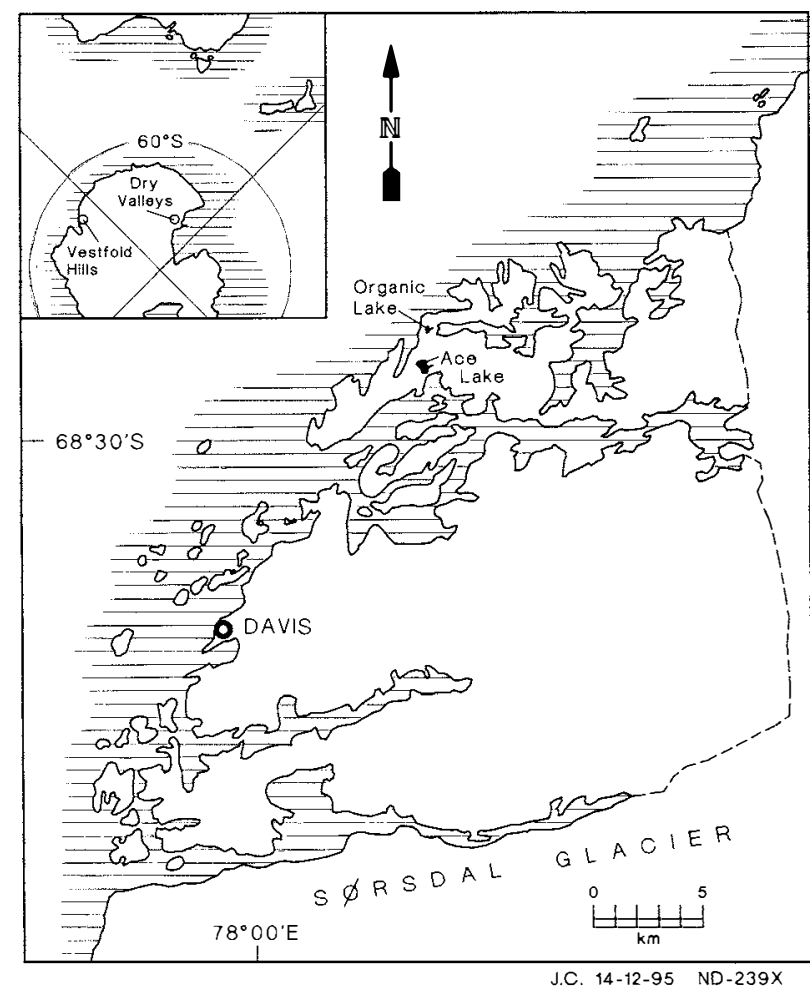

FIG. 1 - A map of the Vestfold Hills showing the locality of Organic Lake and Ace Lake. The inset shows the position of the Vestfold Hills and Dry Valleys regions on the continent of Antarctica. 
data are purely observational, and no information regarding water levels prior to commencement of the observations can be obtained.

As water level increases or decreases, lake area will also increase or decrease. The area can be measured from aerial photographs, though not as accurately as by direct measurement. The relationship between water level and lake area will not be trivial and cannot be determined without first accurately surveying the morphology of the lake basin. However, general information regarding trends in water level can be obtained. The first useful aerial photographs of the Vestfold Hills area were taken in 1947, and many sets of photographs have been taken since then. It is clear from comparisons of these photographs that water levels were considerably lower in the 1940 s than at present.

In this paper we describe a further method for obtaining information about palaeo- and current water level variations, i.e. the consideration of the density structure of meromictic lakes. There are approximately 30 meromictic or permanently stratified lakes and marine basins in the Vestfold Hills (J.A.E. Gibson, pers. obs.). The stratification in these lakes is maintained by the increases of salinity, and thus density, with depth. The lakes range widely in depth (5$60 \mathrm{~m}$ ) and salinity $\left(5-200 \mathrm{~g} \mathrm{~kg}^{-1}\right)$ and exhibit a variety of structural features in the water columns, including sharp pycnoclines (abrupt changes in density) which contrast with considerable intervals of essentially isopycnal water. The lakes are derived from seawater which was trapped as the land rose due to isostatic rebound over the last 8000 years (Bird et al. 1991). Since isolation, many of the lakes have experienced negative water balances and so have developed into hypersaline water bodies with surfaces close to or below current sea level.

Some of the effects of changing water levels on the density strucrure of meromictic lakes of the Vestfold Hills are also described. Knowledge of these effects can be used to reconstruct past minimum water levels and possibly date the periods of minimum water balance.

\section{MATERIALS AND METHODS}

Organic Lake $\left(68^{\circ} 27^{\prime} \mathrm{S}, 78^{\circ} 12^{\prime} \mathrm{E}\right)$ and Ace Lake $\left(68^{\circ} 28^{\prime} \mathrm{S}\right.$, $78^{\circ} 10^{\prime} \mathrm{E}$ ) are located on Long Peninsula in the northern part of the Vestfold Hills, east Antarctica (fig. 1).

All conductivity, density and temperature profiles were recorded when the lakes were covered by a layer of ice, which ranged in thickness from $0.4-1.8 \mathrm{~m}$, depending on the lake and the time of year. Access to the water column was gained by drilling a hole with a motorised ice auger. All water depths were recorded from the air/water interface within the ice hole.

Water temperatures were measured using a submersible data logger (SDL - Platypus Engineering, Hobart, Tasmania). Profiles were recorded by lowering the SDL into the lake in 0.1 or $0.2 \mathrm{~m}$ steps, depending on the depth of the lake. The SDL was left at each depth for 30 secs, in order to attain thermal equilibrium. The accuracy of the temperature measurements was $\pm 0.01^{\circ} \mathrm{C}$. Some temperature data for Organic Lake has been published previously (Franzmann et al. 1987, Gibson et al. 1989).

Density profiles were recorded by one of three different methods. The SDL also recorded electrical conductivities, which, for lakes such as Ace Lake with salinity close to seawater, can be converted to densities, using the algorithms derived for marine waters by Fofonoff \& Millard (1983). These algorithms have limitations in their application to produce water densities for hypersaline lakes such as Organic Lake; however, the in situ conductivities obtained using the SDL allow an approximate profile of lake structure to be plotted. In situ density and temperature profiles were also recorded during the period 1989-92, using an Anton Paar DMA 35 submersible density meter (accuracy $\pm 0.001 \mathrm{~g}$ $\mathrm{kg}^{-1}$ ). Finally, a very accurate density profile of Organic Lake was recorded in December 1992 by carefully pumping water from discrete depths (depth interval $0.1-0.2 \mathrm{~m}$ ) and determining the density of the water at $20^{\circ} \mathrm{C}$ with an Anton Paar DMA 55 densitometer in the laboratory (accuracy $\pm 0.00005 \mathrm{~g} \mathrm{~kg}^{-1}$ ). These densities were converted to in situ densities using the equations of Gibson et al. (1990).

The water level of Organic Lake was measured $( \pm 1 \mathrm{~mm}$ ) on a number of occasions by levelling the surface of the lake to a benchmark (AUSLIG NMS 53, $5.761 \mathrm{~m}$ above sea level) which is positioned close to the edge of the lake. The heights were measured to water surface if the lake was ice free, or to the equilibrium water level in a hole drilled through the ice if ice was present.

\section{RESULTS AND DISCUSSION}

\section{Structure of a Typical Meromictic Lake of the Vestfold Hills}

A typical meromictic lake in the Vestfold Hills can be divided into a number of sections (fig. 2). Throughout winter, the lakes are capped by a layer of ice, which begins to form in February and increases in thickness to between 0.5 and $2 \mathrm{~m}$ by spring. The maximum thickness depends to a large degree on the salinity of the water beneath the ice (the more saline the water, the thinner the ice) but will also reflect the severity of the winter. Ice formation ends when the air temperature is consistently higher than that of the water directly beneath the ice. On most lakes, the ice melts completely by late December, though, in a few low-salinity lakes, it can persist well into January and occasionally does not melt entirely before refreezing begins.

Beneath the ice is a layer of water, termed the epilimnion, which, during active ice formation, is convectively mixed. [The term "epilimnion" is used here as, al though not precisely fitting the current discussion, it seems the best available in the context.] This water is both isothermal and isopycnal as a result of the mixing. The force for the mixing stems from two sources. Firstly, salt is excluded from the ice as it forms, which results in an increase in salinity, and thus density of

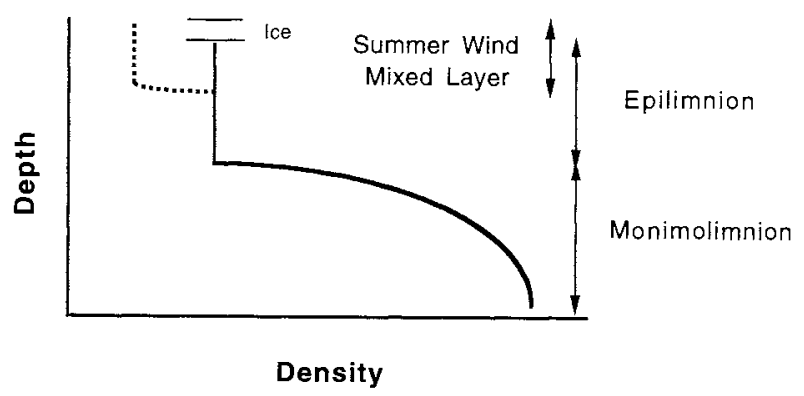

FIG. 2 - Generalised structure of meromictic lakes of the Vestfold Hills. 
the water directly beneath the ice. This leads to downward mixing. Secondly, the base of the layer is warmed by conduction of heat from warmer lower waters, which lessens the density of the water and results in buoyancy. During winter, the temperature of the water of the epilimnion will be at its freezing point as, due to the mixing, the entire layer is in effect in contact with the ice. When, at the end of winter, ice is no longer formed and convective mixing ceases, both thermal and density stratification occur in this layer.

Beneath the epilimnion is a sharply defined boundary, beneath which is the monimolimnion. The density of the water increases continually with depth throughout the monimolimnion, except in a few lakes in which mid-water convection cells occur. The water temperature rises, often sharply, beneath the epilimnion. Temperature can increase throughout the monimolimnion with depth, or can reach a mid-water maximum, beneath which temperature drops to the sediment.

In summer, the ice and epilimnion are replaced by a layer at the surface of the lake that is mixed by wind action. This layer will initially consist of the water derived from the melted ice, which will be of lower salinity and density than the underlying water of the epilimnion at the end of winter. However, more saline water will undoubtedly be entrained into this mixed layer as summer progresses.

\section{Effect of Ice Formation on Water Structure}

The processes that occur in the upper part of the water column of a lake as ice forms provide a model system for the effect of changes in water level, as the ice is essentially equivalent to water lost from the lake by evaporation. When ice begins to form, a convective cell (the new epilimnion) will be set up within the wind-mixed waters, and temperature will drop to the freezing point of the water. As the ice thickens, more salt will be rejected from the ice and essentially integrated over a smaller volume. This will result in an increase in salinity and, therefore, density in this layer. The base of the new epilimnion will at first be constrained by the depth of summer wind mixing but will eventually increase in depth, as the greater density allows deeper penetration into the lake. The temperature of the epilimnion will decrease as the layer becomes saltier, due to the reduction of the freezing point of saline solutions with increasing salinity.

This process will continue throughout the period of ice formation: the epilimnion will steadily penetrate more deeply into the lake and the under-ice water will become colder. At the end of ice formation, three situations can occur. Firstly, if the winter has been less severe than the previous one and, therefore, the ice has not reached the same thickness, the epilimnion might not penetrate to the same depth as in the previous year (fig. 3). This will result in an interval of essentially isopycnal water (which has not undergone any vertical mixing during the year and, therefore, should now be considered part of the monimolimnion) between the base of the current epilimnion and that of the previous year. Secondly, the ice formation can be essentially identical to the previous year, and the epilimnion can penetrate to the same depth as before. Thirdly, if ice formation is greater, the epilimnion can mix to a greater depth, thus entraining into the epilimnion some previously unmixed water from the monimolimnion. Due to ice formation being reasonably consistent from year to year, the change in maximum

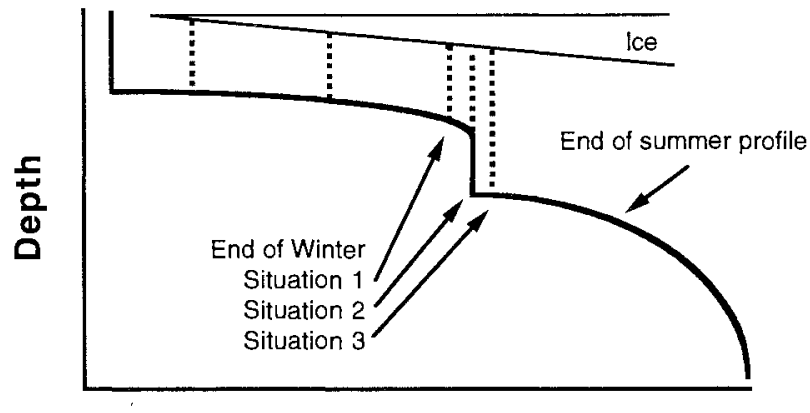

Density

FIG. 3 - Winter process occurring under actively forming ice. As ice forms, the penetration of the epilimnion increases until a maximum is reached at the time of greatest ice thickness. The three possible situations at this time are discussed in the text.

epilimnion salinity and mixing depth due to this factor is likely to be small.

\section{Effect of Changes in Lake Water Level}

The effect of changes in water level of the lake will be similar to those described during winter ice formation but more marked. The effect of decreasing water balance is quite straightforward and is analogous to the formation of a thicker ice cover described above, i.e. the epilimnion becomes more saline. For, although the water level and, thus, the volume of water in the epilimnion are decreasing, the amount of salt dissolved in this layer remains essentially constant. As the lake level drops from year to year, the maximum winter density of the epilimnion will increase, as will the depth of penetration of the epilimniom with respect to the bottom of the lake (fig. 4). The annual minimum epilimnion temperature will drop during periods of negative water balance, as the maximum salinicy increases. Extended periods of decreasing water level will result in penetration of the epilimnion deep into the lake, and so remove any structures (such as pycnoclines and isopycnal zones) previously present in the water column profile. If the water level drops sufficiently, the entire lake will be mixed, completely "resetting" the structure of the lake.

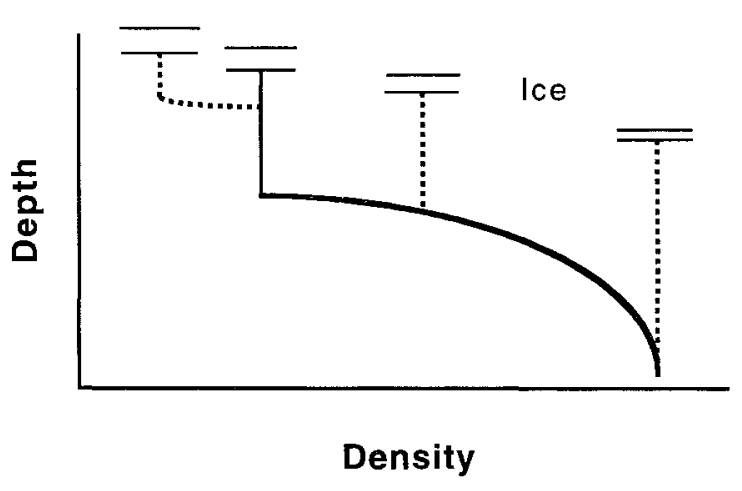

FIG. 4-Effect of water balance on the structure of meromictic lakes. As water level increases, the penetration of the epilimnion increases. Increasing water level results in decreased epilimnetic mixing. 
The situation during periods of increasing lake level is analogous to reduced ice formation. It is to be expected that the base of the new epilimnion after any water level increase will be constrained by the depth of summer wind mixing. The volume of the lake from the surface to the base of the mixed layer will increase due to meltwater input, while the amount of salt will remain the same. Assuming a similar maximum ice thickness to previous years, the salinity of the reduced epilimnion will not reach that of the epilimnion of the year of minimum water level. Simple model calculations suggest that water depth increases as small as $0.1 \mathrm{~m}$, which data suggest can occur quite easily in a single summer, can have a marked effect on the salinity of the reduced epilimnion. The result of a number of successive summers of positive water balance will be as shown in figure 4 . The lake profile will have a considerable depth of near isopycnal water, reaching from the base of the current epilimnion to the depth of mixing at the last period of water level minimum. The presence of these intervals, which we term palaeoepilimnia, is indicative of a prior period of minimum water level and subsequent water level increase. Isopycnal intervals deeper in a lake represent still older periods of minimum water level.

\section{Structural Changes in Organic Lake, 1978-94}

Changes in the density structure of Organic Lake during the period 1978-94 provide an example of the effect of water balance on lake structure. Organic Lake is a small $(300 \mathrm{~m}$ by $350 \mathrm{~m}$ ), shallow (maximum depth c. $7 \mathrm{~m}$ ), meromictic lake on Long Peninsula in the northern part of the Vestfold Hills (fig. 1). The lake is highly saline (maximum salinity $195 \mathrm{~g} \mathrm{~kg}^{-1}$ ) and has been the subject of much research into the effect of this salinity on the biology and chemistry of the lake (Franzmann et al. 1987, Gibson et al. 1994). This interest has resulted in the recording of regular temperature and electrical conductivity profiles.

The firse fine-scale temperature and conductivity profiles were recorded in August 1987 and showed that the lake had a relatively shallow epilimnion, which penetrated to a depth of c. $2.2 \mathrm{~m}$ under $1 \mathrm{~m}$ of ice. Beneath the epilimnion, water

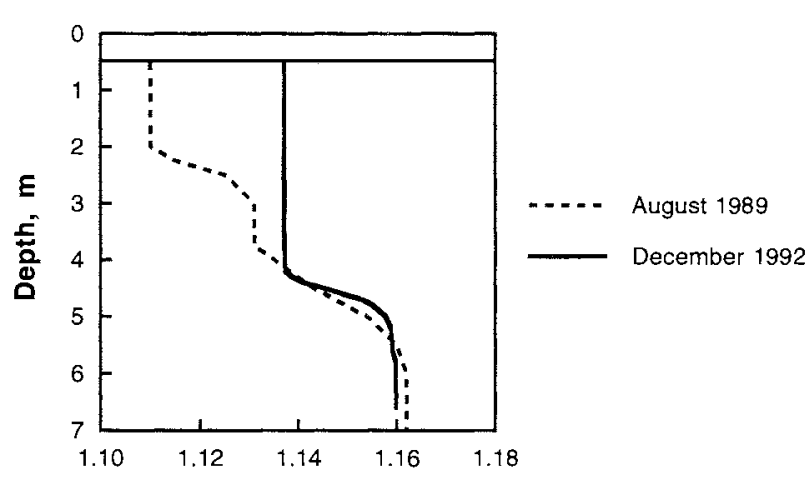

In Situ Density, $\mathrm{g} \mathrm{cm}^{-3}$

FIG. 5 - In situ density profiles $\left(\mathrm{g} \mathrm{cm}^{-3}\right)$ of Organic Lake, August 1989 and December 1992. density increased sharply, until a near isopycnal interval between 3.0 and $3.8 \mathrm{~m}$. Below $3.8 \mathrm{~m}$ the density increased steadily to the sediment. A similar density profile, which is shown in figure 5, was recorded in September 1989. A detailed profile recorded in 1992 revealed that the structure of the lake had changed dramatically (frg. 5). The epilimnion had by then extended to below $4 \mathrm{~m}$, though the rest of the profile was similar to that in 1989. Further profiles recorded between 1992 and 1994 showed that the structure remained essentially unchanged over this period.

From the changes in the structure of Organic Lake that occurred between the 1989 and 1992, it can be deduced that water level dropped over this period. Accurate measurement of water level in January 1989 and September 1994 indicated that the lake had dropped by $0.81 \mathrm{~m}$ over this period (fig. 6). These data are thus consistent with the change in lake structure.

Minimum epilimnion water temperature provides another useful proxy for water depth. From the water level data, it would be predicted that the minimum epilimnion temperature decreased between 1989 and 1992. Figure 6 also shows the lowest recorded winter temperatures in the lake from 1978-94. The general shape of the curve is similar to that of the water level. The temperatures suggest that the water level dropped rapidly between 1989 and 1994, which is consistent with direct measurement. It appears that the water level began to fall in 1990 and continued to do so at least until 1994 . The pre-1989 water temperatures are also consistent with the earlier water level data. Epilimnion temperature and water level were essentially identical in 1984 and 1989, and the low temperature recorded in 1978 corresponds to the lower estimated water level at that time (Franzmann et al. 1987).

Organic Lake is shallow, and thus a relatively small drop in water level will result in a large effect on the structure of the lake. Evidence of less intense periods of low water levels can easily be wiped out by deeper epilimnetic mixing. For example, the step apparent in the 1989 profile of Organic Lake probably reflected water level in 1978, but this information was lost by 1992. Deeper lakes are, therefore, more likely to retain information about older periods of minimum water level.

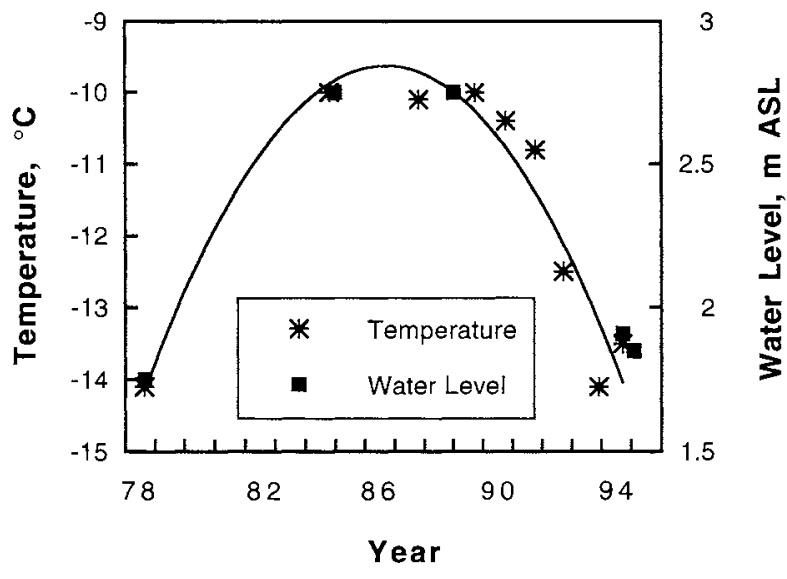

FIG. 6- Changes in Organic Lake surface water level and minimum winter epilimnion temperature, 1978-94. The water level for 1978 is estimated only (Franzmann et al. 1987). The curve shown is arbitrary. 


\section{The Structure of Ace Lake: Implications for Prior Water Levels}

Ace Lake is a meromictic lake in the Vestfold Hills (fig. 1) which is considerably deeper (maximum depth: $25 \mathrm{~m}$ ) and less saline (maximum salinity: $41 \mathrm{~g} \mathrm{~kg}^{-1}$ ) than Organic Lake. A salinity profile recorded on 28 June 1994 is shown in figure 7 . The epilimnion on this date extended to a depth of only $1.8 \mathrm{~m}$ and had a salinity of $11.0 \mathrm{~g} \mathrm{~kg}^{-1}$. Maximum epilimnion salinity recorded during the 1994 winter was $16.5 \mathrm{~g} \mathrm{~kg}^{-1}$, resulting in penetration of the epilimnion to a depth of c. $2 \mathrm{~m}$.

Four palaeoepilimnia, indicated in figure 7 , are evident in the profile. The approximate reduction in water level required to produce the palaeoepilimnia can be calculated as follows. Firstly, the total salt in the lake above the depth at the base of the palaeoepilmnion is estimated from the salinity profile and lake hypsography. The volume of the palaeoepilimnion that would penetrate to that depth is then calculated by dividing the total salt by the salinity at the depth. The position of the surface of the lake is then calculated by determining the water level that gives the required volume above the depth of interest. Figure 7 also shows the estimated positions of the surface of the lake for each of the palaeoepilimnia. The water level drop required to result in cotal mixing of the lake is $5.9 \mathrm{~m}$. This drop is not unreasonable, considering that the water level of Ace Lake has risen by approximately $2 \mathrm{~m}$ between 1975 and 1994 ( $\mathrm{H}$. Burton \& J. Gibson, pers. obs.).

The ages of the palaeocpilimnia in Ace Lake can be determined by a number of methods. Direct observation of salinity and tempcrature profiles in 1991 and 1992 indicated that, in these years, at the end of winter the lake mixed to a depth of c. $7 \mathrm{~m}$, i.e. to the base of the first palaeoepilimnion (N. Roberts, L. Rankin \& T. Pitman, pers. obs.). It is possible that 1994 was the first year that the lake did not mix to this depth. The calculated reduction from current water level required to mix the lake to $7 \mathrm{~m}, \mathrm{c} .1 .6 \mathrm{~m}$, is similar to the expected maximum winter ice thickness for the lake. That the lake did not mix to this depth during the winter of 1994 is probably due to this winter being considerably warmer than that of 1993 , resulting in reduced ice formation. Thus, the age in 1994 of the uppermost palaeoepilimnion was only one or two years.

A profile recorded in November 1975 (Burton \& Barker 1979 ) indicated that the epilimnion extended to a deprh of $5 \mathrm{~m}$ and had a salinity of approximately $27.7 \mathrm{~g} \mathrm{~kg}^{-1}$. Part of this profile is also shown in figure 7 . Considering the lake level has risen by approximately $2 \mathrm{~m}$ since this profile was recorded, the base of the epilimnion in 1975 probably coincided with the base of the first palaeoepilimnion (figure 7). Therefore, it appears that mixing of the second palacoepilimnion, of salinity c. $29 \mathrm{~g} \mathrm{~kg}^{-1}$, occurred prior to 1975.

At least two indirect methods are available to date the palacoepilimnia. Firstly, the distribution of ${ }^{14} \mathrm{C}$ in a meromictic basin in Ellis Fjord (fig. 1) has been used to calculare the age of stratification in the basin (Gallagher et al. 1989). This approach is yet to be applied to Ace Lake.

Secondly, features of the observed salinity profiles controlled by diffusion can be modelled. For example, the boundary between the third and fourth palaeoepilimnia in Ace Lake is not as sharp as the boundaries closer to the surface of the lakc, which suggests that these palaeoepilimnia are of considerable age and have been smoothed by diffusion.

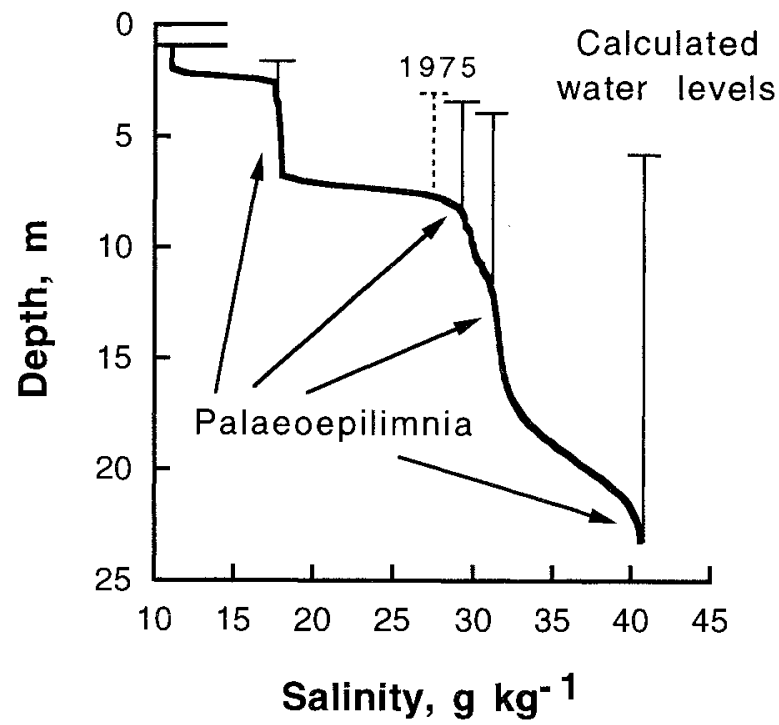

FIG. 7 - Salinity profile of Ace Lake, 28 June 1994. Also shown is part of a profile recorded in 1975 (Burton \& Barker 1979) shifted to greater depths by $2 m$ to account for the rise in water level. The rest of this profile was essentially coincident with that from 1994. Palaeoepilimnia are indicated, and estimated minimum water levels associated with the palaeoepilimnia are shown.

A simple model, considering the diffusion of salt from a more saline, older palaeoepilimnion in to the water above, was developed. The model assumed that the original interface berween the palaeoepilimnia was at $20 \mathrm{~m}$, that the initial salinity of the upper palaeoepilimnion was $30 \mathrm{~g} \mathrm{~kg}^{-1}$ and of the lower $42 \mathrm{~g} \mathrm{~kg}^{-1}$, and that the lake has a conical cross section. Diffusion of salt between horizontally well-mixed layers $0.2 \mathrm{~m}$ thick was determined for time steps of 0.5 years. From the results of the model, it appeared that the upper epilimnion was mixed c. 300 years ago. Similar approaches to modelling the structure of the Lake Vanda in the Dry Valleys (which is different to the lakes of the Vestfold Hills, in that the surface ice does not melt and, therefore, the mixing processes are somewhat different) suggest that minimum lake volume occurred c. 1200 years BP (Wilson 1964).

There are approximately 30 meromictic lakes in the Vestfold Hills, most of which have depths greater than $10 \mathrm{~m}$. Many of the lakes have multi-step density profiles similar to that of Ace Lake. Even though they cannot yet be dated precisely, the palaeoepilimnia evident in the profiles of many of the lakes of the Vestfold Hills provide an important store of information for the calculation of past warer levels, and rherefore water balance, in the lakes of the Vestfold Hills over the last millennium.

\section{ACKNOWLEDGEMENTS}

The authors wish to thank Simon Townsend and Dr Barry O'Grady for collecting the density profiles of Organic Lake in 1989 and 1992 respectively, as well as all other scientists who have recorded profiles of Organic Lake over the years. Discussion with Barry Gallagher helped develop ideas. The logistic support of the Australian Antarctic Division is appreciated. 


\section{REFERENCES}

Bird, M.I., Chivas, A.R., Radnell, C.J. \& Burton, H.R., 1991 : Sedimentological and stable-isotope evolution of lakes in the Vestfold Hills. Palaeogeogr. Palaeoclimatol. Palaeoecol. 84:109-130

Burton, H.R. \& BARKER, R.J., 1979: Sulfur chemistry and microbiological fractionation of sulfur isotopes in a saline Antarctic lake. Geomicrobiol. J. 1:329-340.

ChInn, T.J.H., 1992: Physical hydrology of the Dry Valleys lakes. In LAKES OF THE MCMURDO DRY VALLEYS. Antarctic Research Series 56. AGU, Washington: 1-51. FofonofF, N.P. \& MllLard, R.C., 1983: Algorithms for the computation of fundamental properties of seawater. UNESCO Technical Papers in Marine Sciences 44:53 pp.

Franzmann, P.D., Deprez, P.P., Burton, H.R. \& van den Hoff, J., 1987: Limnology of Organic Lake, Antarctica, a meromictic lake that contains high concentrations of dimethyl sulfide. Aust. J. Mar. Freshw. Res. 38: 409-417.

Gallagher, J.B., Burton, H.R., \& Calf, G.E., 1989: Meromixis in an Antarctic fjord: a precursor to meromictic lakes on an isostatically rising coastline. Hydrobiologia 172: 235254.
Gibson, J.A.E., Ferris, J.M, van den Hoff, J. \& Burton, H.R. 1989: Temperature profiles of saline lakes of the Vestfold Hills. ANARE Res. Notes 67: 1-75.

Gibson, J.A.E., Ferris, J.M. \& Burton, H.R., 1990: Temperature-density, temperature-conductivity and conductivity-densicy relationships for marine-derived saline lake waters. ANARE Res. Notes 78: $31 \mathrm{pp}$.

Gibson, J.A.E., Xu, I.Q., Franzmann, P.D., Garrick, R.C. \& Burton, H.R., 1994: Volatile fatty and dissolved free amino acids in Organic Lake, Vestfold Hills, East Antarctica. Polar Biol. 14: 545-550.

McKay, C.P., Clow, G.D., Wharton, R.A. \& Squyres. S.W. 1985: Thickness of ice on perennially frozen lakes. Nature 313: 561-562.

Wharton, R.A., McKay, C.P., Clow, G.D., Andersen, D.T., Simmons, G.M. \& Love, F.G., 1992: Changes in ice cover thickness and lake level of Lake Hoare, Antarctica: Implications for local climate change. J. Geophys. Res. 97: 3503-3513.

WILSON, A.T., 1964: Evidence from chemical diffusion of a climatic change in the McMurdo Dry Valleys 1200 years ago. Nature 201: 176-177.

(accepted 14 February 1996) 